展望

\title{
人間の海中活動に関する 実験研究の現況
}

\section{緒}

言

地球表面の70パーセントを占め る海洋という領域に対して, 有史 以来ごく最近までは人類はその表 面ないしはわずかに水面下数十メ 一トル程度を行動し，海中資源の 利用としては漁業以外には目ぼし いものを期待していなかったよう に思われる.

それがこの十数年来, 一部の進 取的な人々の努力によって, 海中 や海底の水産, 鉱物資源とか, 海 水のもつ潜在エネルギの活用と か, あるいは動植物の養殖とか海 中観光とか, レジャ一産業とか, または軍事的利用とかの可能性が 認識されて,にわかに海洋の水面 より下方への人間活動が盛んに行 なわれ，その将来への大規模な発 展が予想されるようになった。

わが国では昨年春頃から，いわ ゆる海洋開発はムード的にはブー ム状況を呈している．海洋は広い が, その深さは, 広さに比べれば 大したことはない.もっとも深い ところは 11,000 メートル前後だ が, こんな深い海淵は極めて小範 囲で, 全海洋のうち 6,000 メ一ト ルより深い部分は面積でいえばわ ずかに 2 パーセント位しかない。

一方いわゆる大陸棚領域, すな man-in-sea, by M. Hori

\section{堀 元 美}

わち大陸の近海で棚状を呈する浅 い部分の深さはだいたい200メー トル以内で，この範囲の水域は全 海洋の面積の 8 パーセント位であ る.

当面の課題はこの大陸棚の部分 の海中，海底を開発することであ る.開発の目的は，いろいろな意 味での資源を獲得し活用して経済 的な利益を挙げることや，軍事的 な目的に利用することである.

しかし，そのような具体的活動 にはいる前にこれよりも一歩先行 して, 海洋（海中, 海底）の性質 を調査し，海そのものに対する理 解を深めなければならない，具体 的な利用の段階はそのすぐ後につ いて進んで行くであろう，学術的 な調查研究も, 具体的な利用活動 も水面の上からだけでは不十分で 話にならない。そこでロボット的 な道具を水中に入れてやることも 考えられているが, 何としても人 間自身が水中深く下りて行くこと が必要である. それには潜水艇の ような容器にはいって行くか, あ るいは直接に水圧を身体にうけて 潜入するかということになる.こ の目的で，ただ誢き空から視覚的 に観察し、マニピュレー夕を使っ て標本を採取したり，遠隔操作の 計器で観測するという範囲では潜
水艇を使えばよい.

そのような潜水艇ではすでに 11,000 メトルの世界最深海に達 し得るものも 3 種類ぐらい出来て いる. また学術研究目的または将 来の資源獲得の準備調査のため に, 6,000メートル以内の海中を 探るような潜水艇も，いろいろの 能力のものが多く造られている.

水面より下方へ 1 キロから 6 キ 口程度潜るということは, 人間常 住の水上の世界を隔たる距離から 見れば何でもないが，未知の暗黒 世界へ危険を冒して下りて行き, $2 \sim 3$ 人ぐらいのチームで小さい 艇を操縦して活動するには, 心理 的にも生理的にも決して問題は少 なくない，一義的にいって潜水艇 は, 曲型的なマン・マシン・シス テムとして取扱われなければなら ない.これが理解出来ていない技 術者の造った潜水艇では，優れた ものは出来ないことは自明の理て ある。

潜水艇は水面直下から最深海ま でを活動範囲としているが，人間 自身が直接水中に出て行ける範囲 の浅い海では, その作業の精度の 上では人間の活動の方がはるかに 優れた成果を示す。そこでわれわ れは, 出来るだけ人間の水中活動 の能力を高め, その範囲を拡げる 
ことを望ましと考える.

今日の段階では深さの方では 3 00メートル程度までの可能性が予 想されるが，現実に今のところ潜 入可能の深さは 100 メートル, 活 動可能は50メートル程度と見られ る. 潜水者の水中活動の方法と要 具や設備が生理学, 心理学, 医学 的な知見を基礎とし, 工学的，技 術的手段によって実現されること を考えればここに当然人間工学が 登場しなければならないことは明 らかであろう。

\section{海中環境が人間に及ぼす影響}

海中における人間の活動の諸問 題についてはひと通り別項に揭げ ておいた。ここでは水中活動の中 核的問題である潜水法とその関連 事項の進歩の現状についてごくあ らましのところを紹介する.

人間がある範囲の水深まではそ の水圧に耐えて水中に生存し活動 することが可能であると判り，い わゆる軟式潜水服にハード・ハッ ト（ヘルメット）を組合せたもの を着用し, 服の内部にゴム・ホー スを通じて圧力ある空気を送って 潜水する方法が確立されたのは, 1820年頃のことであったようだ. そしてその深度は10メートル前後 とされていた。

これ以上の深度に潜入してか ら，急に水面に浮上すると身体に 異常を生ずることが知られた。こ れは,はじめには潜函病と呼ば れ，後には Bends といわれ，今 日では減圧症と称せられているも のであった。

その対策がいろいろ研究された 結果, 1878 年に Paul Bert が環 境圧力の減少を徐々に行なうこと
によって Bends を避け得ること を立証し，1908年になって Haldane その他の人々が，階段的減 圧法を開発し，ここに減圧症対策 が確立した。

それ以後の研究に伴ない潜水可 能深度は 100 メートル前後に増大 して行ったが，同時に別の問題が 起こって来た。それはいわゆる窒 素麻酔現象であった。

1930年頃その対策としてへリウ ム一酸素混合気を用いて空気の代 りとし,さらに潜水具の内部に炭 酸ガス吸収装置をも備えるように なった，空気中の窒素をへリウム に置換えることは，高圧状態での 窒素の麻酸作用を排除するには有 効だったが，つぎには高い分圧の もとにある酸素を呼吸すると, 容 積的には少なくても酸素の絶対量 が増加し，こんどは潜水者が酸素 中毒にかかることが判った。この 現象に対しては酸素の分圧を下げ ること,すなわち, ヘリウム一酸 素混合気中の酸素量を少なくする ことによって解決が出来た。

今日では潜水深度, 時間に対応 して呼吸用気体はそれぞれに処方 されることになっている.

1957年アメリカ海軍のニューロ ンドン潜水艦基地にある海軍医学 研究所では，いかにして潜水者の 海中活動時間を延長し得るかとい う研究が行なわれた。特別処方の 混合気を用い, 炭酸ガス除去設備 を備えた潜水装置によって潜水可 能深度を増大しても, 海底滞在時 間が限られ，しか子減生しながら 水面上に復帰するための時間が長 いのは，海底作業は極めて高価な ものとなって，とても実用にはな らないのである。

その研究の結果「飽和潜水法」
Saturation diving という方式が 案出された。

これはひとつは深度その他の条 件に応じて潜水者に呼吸させるた めの混合気体の成分をいかにに処 方すべきかを見出すこと，また一 方ではそのような気体によって身 体内部の一切の細胞と液体とが飽 和された状態で人体に異常を生ず ることはないかという問題, さら にそのような飽和状態（高圧下に おける）から再び水上における通 常の状態に戻すためにはどのよう な減圧過程を経過すれば可能であ るかという問題を含むものであっ た.

\section{Man-in-Sea 計画}

1962年 9 月 E. A. Link 氏の指 導によって R. Stenuit 氏は地中 海 Ville francheにおいて深度 60 メートルの海底に26時間の滞在活 動を行なった。このとき潜水者は Link 氏の創製したアルミニウム 製の長さ3.35メートル，直径91.5 センチの円筒に入って, 内部を予 定の水深に相当する圧力（酸素 3 \%, ヘリウム $97 \%$ の混合気体) に して沈下し, 着底後扉をひらいて 海中に出入した。休覟時はその筒 内にはいって混合気体（外海と等 圧）中で休覟し, 時々外部の海中 に出て活動した。

上昇時は筒内にはいって, 海底 の圧力を保ったままで母船上に引 上げられ，そのまま母船上で簡外 からの監察をうけながら, 母船上 の Link 氏の指導によって所定通 り減圧を行なってこの最初の長時 間潜水実験は成功を収めたのであ った. 同じアイデアにもとづく,よ り大規模な長時間潜水はその後相 続いて, フランスとアメリカで行 
表 1 主要な潜水実験の概要

\begin{tabular}{|c|c|c|c|c|c|c|c|c|}
\hline 作 業 名 & 年 月 & 場 所 & 水 深 & 時間 & 人員 & 滞底様式 & 呼吸気体 & 指 導 者 \\
\hline $\begin{array}{l}\text { MAN IN } \\
\text { SEA }\end{array}$ & $1962-9$ & 地 中 海 & $60 \mathrm{~m}$ & $26 \mathrm{~h}$ & 1 & $\begin{array}{l}\text { アルミニウム } \\
\text { 円筒 }\end{array}$ & $\begin{array}{rl}3 \not 6 & \mathrm{O} \\
97 \not 6 & \mathrm{He}\end{array}$ & E. A. Link \\
\hline $\begin{array}{l}\text { Precontinent } \\
\text { I }\end{array}$ & $1962-9$ & 地 中 海 & $9.1 \mathrm{~m}$ & 7 日 & 2 & $\begin{array}{l}\text { DIOGENE } \\
\text { 鋼製水平円筒 }\end{array}$ & 空気 & $\begin{array}{l}\text { J. E. Cousteau } \\
\text { OFRS }\end{array}$ \\
\hline $\begin{array}{l}\text { Precontinent } \\
\text { II }\end{array}$ & $1963-6 / 7$ & 紅 海 & $10 \mathrm{~m}$ & 1 月 & 5 & $\begin{array}{l}\text { STAR HO- } \\
\text { USE } \\
\text { 鋼製星形居室 }\end{array}$ & 空気 & $\begin{array}{l}\text { J. E. Cousteau } \\
\text { OFRS }\end{array}$ \\
\hline $\begin{array}{l}\text { MAN IN } \\
\text { SEA }\end{array}$ & $1964-6 / 7$ & バ八 マ & $132 \mathrm{~m}$ & $49 \mathrm{~h}$ & 2 & $\begin{array}{l}\text { SPID } \\
\text { コム製テント }\end{array}$ & $\begin{array}{rl}4 \% & \mathrm{O} \\
96 \% & \mathrm{He}\end{array}$ & E. A. Link \\
\hline $\begin{array}{l}\text { SEALAB } \\
\text { I }\end{array}$ & $1964-7$ & バーミュ & $59 \mathrm{~m}$ & 11日 & 4 & $\begin{array}{l}\text { 鋼日製葉巻型 } \\
\text { 水平円筒居室 }\end{array}$ & $\begin{aligned} 16 \% \mathrm{~N} \\
4 \not 6 \mathrm{O} \\
80 \% \mathrm{He}\end{aligned}$ & $\begin{array}{l}\text { G. F. Bond } \\
\text { U. S. Navy }\end{array}$ \\
\hline $\begin{array}{l}\text { MAN IN } \\
\text { SEA }\end{array}$ & $1965-8$ & $\begin{array}{l}\text { リンデ研 } \\
\text { 究所 }\end{array}$ & $\begin{array}{l}198 \mathrm{~m} \\
シ ミ ュ レ\end{array}$ & $48 \mathrm{~h}$ & 2 & $\begin{array}{l}\text { 高圧実験タン } \\
ク\end{array}$ & $\begin{array}{c}4 \% \mathrm{~N} \\
1.85 \% \mathrm{O}\end{array}$ & $\begin{array}{l}\text { Ocean Syste- } \\
\text { ms }\end{array}$ \\
\hline SEALAB II & $1965-9$ & $\begin{array}{l}\text { カリフォ } \\
ル=ア\end{array}$ & $\begin{array}{l}-r \\
66 \mathrm{~m}\end{array}$ & $\begin{array}{l}15 \text { 日 } \\
30 \text { 日 }\end{array}$ & & $\begin{array}{l}\text { 鋼製円筒型居 } \\
\text { 室 }\end{array}$ & $\begin{array}{r}94.15 \% \\
\mathrm{He} \\
16 \% \mathrm{~N} \\
4 \% \mathrm{O} \\
80 \% \mathrm{He}\end{array}$ & $\begin{array}{l}\text { G. F. Bond } \\
\text { U. S. Navy }\end{array}$ \\
\hline $\begin{array}{l}\text { Precontinent } \\
\text { III }\end{array}$ & $1965-10$ & 地 中 海 & $96 \mathrm{~m}$ & 24 日 & 6 & $\begin{array}{l}\text { 大型球型 } \\
2 \text { 層居住室 }\end{array}$ & $\begin{array}{ll}1 \% & \mathrm{~N} \\
2 \% & \mathrm{O} \\
97 \% & \mathrm{He}\end{array}$ & $\begin{array}{l}\text { J. E. Couste- } \\
\text { au OFRS }\end{array}$ \\
\hline $\begin{array}{l}\text { SEALAB III } \\
\text { 予備実験 }\end{array}$ & 1968 & $\begin{array}{l}\text { 米海軍深 } \\
\text { 海潜水実 } \\
\text { 験隊 }\end{array}$ & $251 \mathrm{~m}$ & $48 \mathrm{~h}$ & 5 & $\begin{array}{l}\text { 高圧実験 タン } \\
ク\end{array}$ & $\begin{array}{l}\text { Heliox } \\
\text { 詳細不明 }\end{array}$ & U. S. Navy \\
\hline
\end{tabular}

なわれている. その主たるものを 表 1 に示す，表で見る通り，3つ の大きな流れがある.

その 1 は, アメリカの E. A. Link 氏（有名な航空機操縦訓練 装置 Link trainer の発明者) に よる，上記の実験からはじまった ものである. 上に述べたアルミニ ウム製の Link diving cylinder

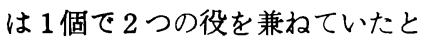
も見られるが，その後，このアイ デアは大きく発展して 3 つのニ ットに分割されるようになった。

（1）潜水者を水面上の母船から 海中の予定位置まで運び, また逆 のルートで回収し，しかもその途
中は任意の圧力の呼吸気体の中に 安住させたままあるいは所要の減 圧を施しながら移動浮上させるた めの一種の水中エレベー夕（これ はその役目の中のもっとも重要な ものに従って Submersible decompression chamber $=$ SDC すな わち潜水減圧室と呼ばれている).

（2）海中に設けた居室で内部は 海水と等しい圧力の呼吸気体で充 たされ，その下方に海に通ずる出 入口をもち，潜水者はこの出入口 から室内に入り, 室内では潜水具 を脱して休憩することも，観測そ の他の仕事をすることも出来るよ うな水中居住室 (Link の実験で
はこれをゴム製の可搬式のむのと したので Submersible portable inflatable dwelling=SPIDと呼 んだが，他の場合には，これはよ り大型の固定式の鋼製構造物とし て Underwater habitat などと 呼ばれている).

（3）潜水者が水中での用務の終 った後は, SDC によって高圧の まま速かに水上に運ばれると, 直 ちに船の上にあるより大型で，よ り設備のよい船上減圧室 Deck decompression chamber をドッキングして, 圧力の変化を うけずにSDC の方に移り,より Comfortable な状態て休養し, 食 
事, 読書, 睡眠などを行ないなが ら, DDC 外部からのモニ夕を受 けつつ所要の減圧過程を経過して 常圧状態に復帰する.

以上のような一連の方法を開発 確立したのがLink 氏の業績であ る. 同氏はこれと平行して, 潜水 夫の活動母艇として，いわば SD $\mathrm{C}$ 運動能力を与えたような小さい 潜水艇を計画, 建造して水中作業 組織を編成し, 今日では Ocean System 社の指導者として実際の 海中作業に従事している.

このようなアイデアで人間を海 中に活動させる極めて野心的な企 画をLink 氏は Man-in-Sea Project と名づけた.

\section{有名な 2 つ実験系列}

フランスではまた別個に海軍大 佐 J. Y. Cousteau 氏が早くから 海中活動に興味をもって熱心に開 発を行なっている. 同氏はいわゆ る Diving saucer $=$ Soucoupe $($ 水 中円艋型の潜水艇を造り，また Conshelf I, II, III (Precontinent I, II, III) という大規模 な海底居住実験を実行し, 1965年 10月の Conshelf III 実験では 6 名の人間が 96 メートルの海中で 24 時間を過すというところまで成功 している.

もうひとつの系列は, 海軍軍医 大佐 G. F. Bond 氏を中心とする アメリカ海軍の海中活動研究であ る. 同海軍は生理学用の大規模な 実験装置をもっているので, 予備 実験を精密に行なっている.

実際の海中での実験はすでによ く知られているSEALAB I, II, IIIで，I と II は表 1 に見る通り， ほとんど带こおりなく成功した。

しかし SEALAB III は本年 2
月 California $つ$ St. Clemente 島近海の海底に海中居住研究室を 沈置した際, 在来経験していなか った深度であるため, 装置に不備 の個所があることが発見され,さ らにその倹査と処置のために潜水 者の 1 人が死亡するという事故が 起こったので, 今のところは無期 延期のかたちである.

アメリカ海軍の実験体制は，わ れわれから見ると資金の投入の点 でも, 万全を期した各方面の準備 の点でも，まことに羡しいほどの 大規模なものなのだが, それでも こういう障害に出あっている.こ れは今後の研究計画上大いに注意 を要することである.

\section{深海潜水の実験}

長期滞底を目的としないで, 潜 水深度の方のレコードを造ること も，いままでに繰返して試みられ ている.

1962年に Hannes Keller とい う人が California で独特の気体 を呼吸し， SDC に乗って 1,000 フィート (305メートル)の水中 に潜り, 3 分間海中に出てから浮 上している.このときもう 1 人の 同行者があったが, 上昇の際にS DCが何かの支障で気密を保つこ とが出来ず, 滅王過程が計画より も短縮された結果となって, 同行 者の方は潜水病にかかり, ついに 死亡した.

これに外の実際の海での潜水の 実例は大体 150 メートル程度であ る.

飽和潜水と深々度潜水の組合女 を実現するため, 陸上の実験装置 の中でのレミュレート潜水は、ア メリカ海軍とイギリス海軍とがし きりに行なっている.
イギリス海軍では，1964年に Portsmouth の実験タンクを使っ て183メートルで 4 時間, $244 x-$ トルで 2 時間という実験を行なっ た.これらの場合の滅圧所要時間 はそれぞれ40時間と51時間という ことであって, このくらいの滞底 では総計の水中時間に対し実際滞 底時間はそれぞそ10分の 1 および 25分の 1 ということになりまった く効率の悪い作業となることが判 る.

SEALAB III の予備実験として アメリカ海軍の深海潜水実験隊が 1968年はじめ頃に行なった実験は つぎのようなものである.

最初 5 名の潜水者が 183 メート 儿相当の dry chamber 内に24時 間滞在,つぎに内 2 名だけが wet chamber に入り251.5メートル相 当に加圧し, つづいて dry chamber の方も 251.5 メートル相当圧 として24時間を経過, つぎに内 2 名だけが 3124 メートルを13分間 体験.

このようにして全員 5 名が251. 5 メートルまたはそれ以上で 48時 間経過の後次第に減圧を行なっ た。

この実験によって得られた結果 によると

○完全な飽和状態になるのはその 圧力で 24 時間経過した後である 。減圧所要時間を決定する要素は 人体の組織の飽和の程度である などの事実が知られたという.

以上に紹介したとことは, いま までの海中生活の体験中の基本的 問題のごく大要だけであって,こ とに水中長期滞在に伴う活動作業 の関連事項については触れていな い. 